\title{
MULTIVARIATE STATISTICS APPLIED TO IRRIGATION WATER QUALITY DATA OF A WATERSHED IN THE SEMIARID REGION OF BRAZIL ${ }^{1}$
}

\author{
RAIMUNDO FERNANDES DE OLIVEIRA JÚNIOR ${ }^{2 *}$, LUIS CÉSAR DE AQUINO LEMOS FILHO ${ }^{3}$, \\ RAFAEL OLIVEIRA BATISTA ${ }^{3}$, LARISSA LUANA NICODEMOS FERREIRA ${ }^{2}$, LUCAS RAMOS DA COSTA ${ }^{2}$, \\ MATEUS PESSOA CAMINHA ${ }^{3}$
}

\begin{abstract}
Water scarcity is one of the main problems in the Semiarid region of Brazil, which can be mitigated by water resource management strategies. The objective of this work was to classify waters of a watershed in the Semiarid region of Brazil and select the water attributes that most affect the quality of waters used for irrigation (QWI), using multivariate statistics. The study area was the Riacho da Bica watershed, which is between the municipalities of Portalegre and Viçosa, Rio Grande do Norte, Brazil. The QWI was determined using water samples from 15 collections carried out from 2016 to 2018, in five specific points of the watershed, starting in the spring and following the water course. The water attributes evaluated were: electrical conductivity (EC), potential hydrogen $(\mathrm{pH})$, and sodium $\left(\mathrm{Na}^{+}\right)$, potassium $\left(\mathrm{K}^{+}\right)$, magnesium $\left(\mathrm{Mg}^{2+}\right)$, calcium $\left(\mathrm{Ca}^{2+}\right)$, carbonate $\left(\mathrm{CO}_{3}{ }^{2-}\right)$, chloride $\left(\mathrm{Cl}^{-}\right)$, and bicarbonate $\left(\mathrm{HCO}_{3}{ }^{-}\right)$contents. The water quality data were subjected to multivariate statistics through factorial analysis (FA) and principal component analysis (PCA). The application of multivariate statistics through FA-PCA generated four principal components. The attributes that most explained the QWI variation were potassium, calcium, and $\mathrm{pH}$ for Factor 01 , and sodium and RAS for Factor 02. The watershed waters were classified as low risk of salinity and medium risk of sodicity $\left(\mathrm{C}_{1} \mathrm{~S}_{2}\right)$ for irrigation purposes.
\end{abstract}

Keywords: Water Resources. Salinity. Agriculture.

\section{ESTATÍSTICA MULTIVARIADA APLICADA A QUALIDADE DA ÁGUA PARA IRRIGAÇÃO EM MICROBACIA PERENE DO SEMIÁRIDO BRASILEIRO}

\begin{abstract}
RESUMO - A escassez hídrica se configura como um dos principais problemas do semiárido, devendo ser mitigado pelas estratégias de gestão dos recursos hídricos. O objetivo desse trabalho foi classificar a água e utilizar a estatística multivariada, como uma ferramenta para selecionar os atributos que possuem maior influência na qualidade da água utilizada para fins de irrigação, em uma microbacia hidrográfica do semiárido brasileiro. Á área de estudo está inserida na microbacia hidrográfica do Riacho da Bica, entre os municípios de Portalegre-RN e Viçosa-RN. A determinação da qualidade da água para fins de irrigação foi realizada por meio de quinze campanhas de coleta de amostras de água em cinco pontos específicos do Riacho da Bica, iniciando na nascente e seguindo o curso d'água, no período de 2016 a 2018, sendo avaliados atributos como condutividade elétrica $(\mathrm{CE})$, potencial hidrogeniônico $(\mathrm{pH})$, sódio $\left(\mathrm{Na}^{+}\right)$, potássio $\left(\mathrm{K}^{+}\right)$, magnésio $\left(\mathrm{Mg}^{2+}\right)$, cálcio $\left(\mathrm{Ca}^{2+}\right)$, carbonato $\left(\mathrm{CO}_{3}{ }^{2-}\right)$, cloreto $\left(\mathrm{Cl}^{-}\right)$, bicarbonato $\left(\mathrm{HCO}_{3}{ }^{-}\right)$. Os dados de qualidade de água foram submetidos a estatística multivariada com a realização da análise fatorial (AF) e a análise de componentes principais (ACP). A aplicação da estatística multivariada, gerou através da ACP/AF, quatro componentes principais. O $\mathrm{pH}$, potássio e cálcio foram os atributos que mais explicam a qualidade da água para irrigação para o Fator 01, para o Fator 02 os atributos sódio e RAS. A água da microbacia hidrográfica foi classificada para fins de irrigação como baixo risco de salinidade e médio risco de sodicidade $\left(\mathrm{C}_{1} \mathrm{~S}_{2}\right)$.
\end{abstract}

Palavras-chave: Recursos Hídricos. Salinidade. Agricultura.

\footnotetext{
${ }^{*}$ Corresponding author

${ }^{1}$ Received for publication in $05 / 27 / 2020$; accepted in $03 / 18 / 2021$.

Paper extracted from the doctoral thesis of the first author.

${ }^{2}$ Department of Agronomic and Forestry Sciences, Universidade Federal Rural do Semi-Árido, Mossoró, RN, Brazil; junior182@outlook.com - ORCID: 0000-0003-1332-3709, larissa.nic@hotmail.com - ORCID: 0000-0003-2375-4975, lucas_ramos@facenemossoro.com.br - ORCID: 0000-0002-8710-1589.

${ }^{3}$ Department of Environmental and Technological Sciences, Universidade Federal Rural do Semi-Árido, Mossoró, RN, Brazil; lcalfilho@ufersa.edu.br - ORCID: 0000-0001-8527-2686, rafaelbatista@ufersa.edu.br - ORCID: 0000-0002-3083-6808, mateuspessoa14@hotmail.com - ORCID: 0000-0002-9941-0362.
} 


\section{INTRODUCTION}

Water scarcity in the Semiarid region of Brazil is one of the main causes of socioeconomic problems in the region, which is characterized by long drought periods that cause different effects, such as losses in agricultural crops, increases in rural unemployment, water shortage for populations, and migrations from rural areas to urban centers, which have been frequently present in the Semiarid region (ZANELLA, 2014).

Hydrological processes are strongly affected by the local climate status and water limitations; long dry periods cause perennial rivers and streams to change to seasonal. In addition, the soil water absorption capacity in the Semiarid region is low due to a varied relief and shallow and stony soils. The presence of crystalline soils limits the access to waters of underground aquifers, which are stored in fractures of rocks, but present, however, poor quality (RIBEIRO; OLIVEIRA, 2019).

Irrigated agriculture depends on the water quantity and quality. Water quality is one of the most important factors in the long-term, and the use of saline waters for the irrigation can be a risk to agricultural production (AYERS; WESTCOT, 1999). High salt levels in the irrigation water are harmful to the development of crops and cause obstructions to irrigation systems (GARCIA et al., 2008).

Water quality for agricultural purposes is classified based on the concentration of some ions, such as sodium, potassium, chlorides, and sulfates, and other parameters, such as dissolved solids and electrical conductivity, considering risks of soil salinization, sodification, and alkalinization and toxicity risk to plants (BARROSO et al., 2011).

The evaluation of the quality of waters used for irrigation (QWI) encompasses several physical, chemical, and biological characteristics. According to Almeida (2010), the most common attributes used for these analyses are: hydrogen potential $(\mathrm{pH})$, electrical conductivity (EC), and total dissolved salts, including the ions sodium $\left(\mathrm{Na}^{+}\right)$, potassium $\left(\mathrm{K}^{+}\right)$, calcium $\left(\mathrm{Ca}^{+}\right)$, magnesium $\left(\mathrm{Mg}^{+}\right)$, chloride $\left(\mathrm{Cl}^{-}\right)$, sulfate $\left(\mathrm{SO}_{4}^{+}\right)$, carbonates $\left(\mathrm{CO}_{3}^{-}\right)$, and bicarbonate $\left(\mathrm{HCO}_{3}\right)$.

QWI should not be evaluated only by total salt content, but by the individual concentration of some ions. The excess of some cation and anion salts may harm the soil and growth of plants, depending on their tolerance to these salts.

The combined analysis of several water attributes is carried out using statistical technics that simultaneously analyze the effect of multiple measures on the study subject, which are termed multivariate statistics analysis (HAIR JUNIOR et al., 2009). Multivariate statistics can be used for data collected over time and space, enabling a better information of correlations between the water quality indicators analyzed.
Multivariate statistics analysis enables an interpretation of process of water quality indicators with less complexity and assists in decision making, minimizing costs with laboratorial analyses and data collections (GOMÉZ et al., 2013).

Water quality monitoring produces a large quantity of data due to long evaluation periods and many sampling points, which is often difficult to analyze and interpret (MUNIZ et al., 2019). According to Mostafaei (2014), these data need to be synthesized to be used as tool to assist in decision making for the management of water resources.

In this context, the objective of this work was to classify waters of a watershed in the Semiarid region of Brazil and select the water attributes that most affect the QWI, using multivariate statistics

\section{MATERIAL AND METHODS}

The study area was the Riacho da Bica watershed, which is in the upper mid Apodi River basin, in a mountain region between the municipalities of Portalegre and Viçosa, Rio Grande do Norte (RN), Brazil. The watershed has predominance of intermittent (seasonal) water resources. However, the mid Apodi River basin mid basin has an important water disperser, the plateau of the mountain range of Martins and Portalegre, whose geoenvironmental characteristics favor the formation of swamps of altitude sustained by perennial water springs, which are responsible for the formation of "islands" of moist forest. These springs are explained by their environmental context; the high rainfall depths combined with sedimentary cover characteristics at the mountain range top (Serra do Martins Formation) allows the accumulation of underground water that reemerges in altitudes of approximate $630 \mathrm{~m}$, in the contact between the sedimentary cover and the crystalline base.

The climate of the watershed region is tropical rainy, according to the Köppen classification, with dry winter and a rainy season extending up to July (ÁLVARES et al., 2013). The altitude of the watershed varies from 186 to $660 \mathrm{~m}$, this range is essential for the formation of the Pinga Waterfall, a place of ecological importance that is explored as a tourist point with non-controlled standards.

The spring studied is known as Nascente da bica, which originates the Riacho da Bica stream, in the municipality of Portalegre, RN, Brazil. The sample plan was developed by delimiting the watershed through contour lines and observations of topographical dividers using computational tools.

The quality of waters used for irrigation (QWI) was determined using water samples from 15 collections carried out from 2016 to 2018 in 5 specific points of the Riacho da Bica stream, starting in the spring and following the water course. 
The first sampling point was in the spring of the Riacho da Bica stream, in the Spout Threshold (Portal da Bica) at $620 \mathrm{~m}$ altitude (SP1); the second sampling point was in the a water flow stretch, at downstream to the spring, at the Bath Spout (Banho da Bica) (SP2); following the river course, the third sampling point was before the Pinga Waterfall
(SP3); the fourth sampling point was after the Pinga Waterfall, where a water accumulation is formed by the waterfall and there is a constant presence of visitors (SP4); and the fifth sampling point was in the lower course of the Riacho da Bica stream (SP5). The location of sampling point is shown in Figure 1.

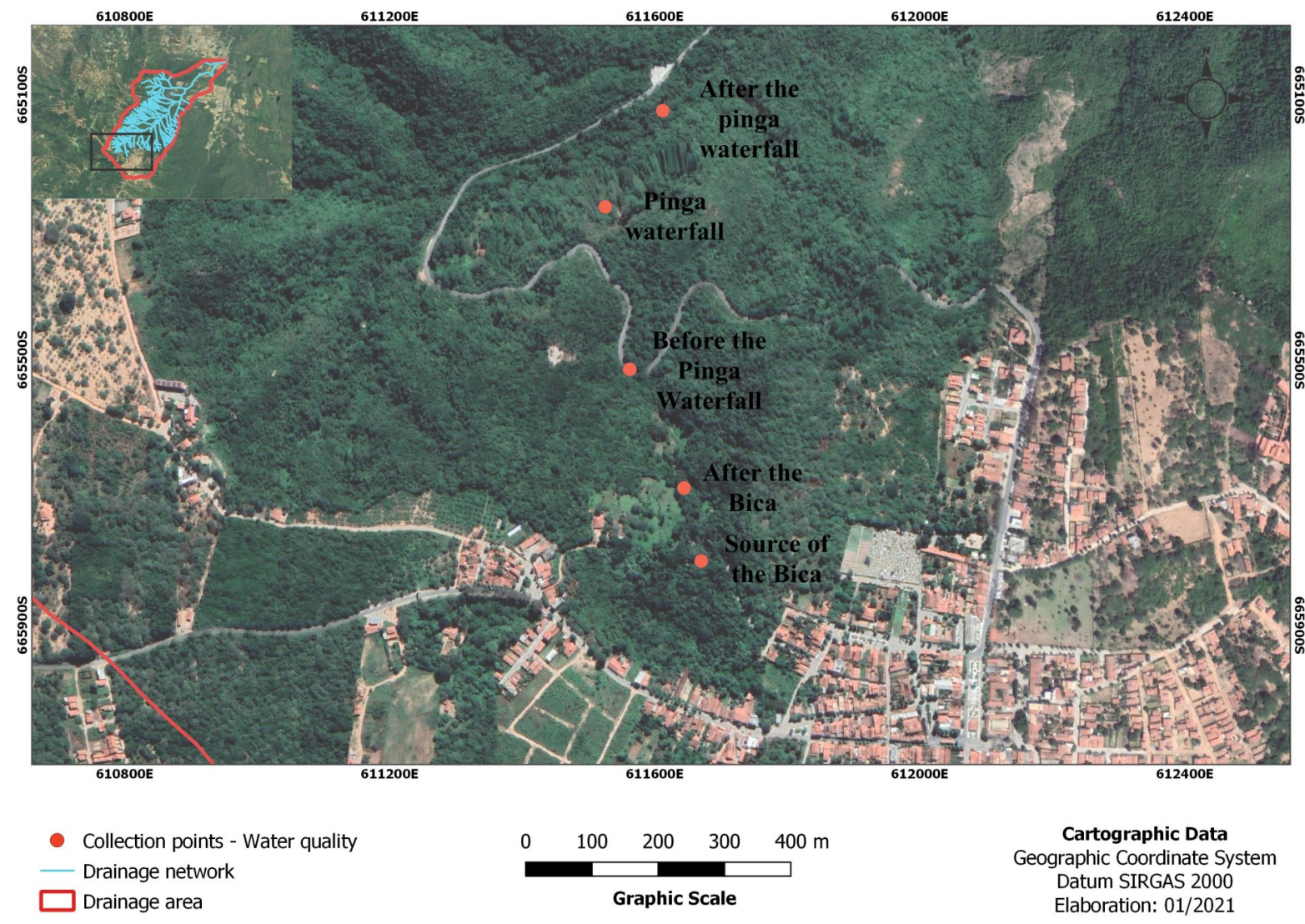

Source: Adapted from Google Earth (2020).

Figure 1. Location of the sampling points used.

The water physical and chemical attributes were determined using simple water samples, which were collected in all sampling points using 1-liter bottles. The bottles were washed three times with running water from the Riacho da Bica, identified, and then immersed to a maximum depth of $30 \mathrm{~cm}$ of water column for the sample collection in each sampling point. The samples were promptly placed in isothermal boxes for refrigeration and taken to the Laboratory of Soil, Water, and Plant Analysis of the Federal Rural University of the Semiarid Region (UFERSA), within at least 24 hours.

The attributes evaluated to determine the QWI were: electrical conductivity (EC), obtained by using a bench conductivity meter; hydrogen potential $(\mathrm{pH})$, obtained by using a $\mathrm{pH}$-meter; sodium $\left(\mathrm{Na}^{+}\right)$and potassium $\left(\mathrm{K}^{+}\right)$, obtained by using flame photometer; magnesium $\left(\mathrm{Mg}^{2+}\right)$, calcium $\left(\mathrm{Ca}^{2+}\right)$, carbonate $\left(\mathrm{CO}_{3}{ }^{2-}\right)$, chloride $\left(\mathrm{Cl}^{-}\right)$, and bicarbonate $\left(\mathrm{HCO}_{3}\right)$ contents, obtained by titration; sodium adsorption ratio (SAR); and hardness, through specific equations.

The QWI was classified considering risks of soil salinity and sodicity, according to the methodology proposed by University of California Committee of Consultants (UCCC) (AYERS; WESTCOT, 1999), considering the overall mean of the attributes obtained in the 15 collections, in the five points sampled. Table 1 shows the salinity risks based on the electrical conductivity of the water used for irrigation. The correlations between SAR and salinity of the water were used to evaluate the risks of infiltration of sodium in the soil, considering three sodicity classes (Table 2). 
R. F. OLIVEIRA JÚNIOR et al.

Table 1. Classification of the quality of waters used for irrigation, considering the risks of soil salinity.

\begin{tabular}{ccc}
\hline Salinity class & Electrical conductivity range $\left(\mathrm{dS} \mathrm{m}^{-1}\right)$ & Salinity risk \\
\hline $\mathrm{C} 1$ & $<0.7$ & None \\
$\mathrm{C} 2$ & $0.7-3.0$ & Moderate \\
$\mathrm{C} 3$ & $>3.0$ & Severe \\
\hline
\end{tabular}

Table 2. Risks of problems with infiltration of sodium in the soil, according to the water sodicity.

\begin{tabular}{cccc}
\hline \multirow{3}{*}{$\begin{array}{c}\text { Sodium adsorption ratio } \\
\left(\mathrm{mmol}_{\mathrm{c}} \mathrm{L}^{-1}\right)^{0.5}\end{array}$} & \multicolumn{3}{c}{ Sodicity classes } \\
\cline { 2 - 4 } & $\mathrm{S}_{1}$ & $\mathrm{~S}_{2}$ & $\mathrm{~S}_{3}$ \\
& No problems & Moderate problems & Severe problems \\
\hline $0-3$ & $>0.70$ & Electrical conductivity range $\left(\mathrm{dS} \mathrm{m}^{-1}\right)$ & \\
\hline $3-6$ & $>1.20$ & $0.70-0.20$ & $<0.20$ \\
$6-12$ & $>1.90$ & $1.20-0.30$ & $<0.30$ \\
$12-20$ & $>2.90$ & $1.90-0.50$ & $<0.50$ \\
$20-40$ & $>5.00$ & $2.90-1.30$ & $<1.30$ \\
& & $5.00-2.90$ & $<2.90$ \\
\hline
\end{tabular}

Pearson correlation $(p \leq 0.05)$ was carried out for all attributes studied to ensure that they had enough correlations to justify their use in the data matrix for FA. The matrix was obtained through the data analysis function of the Excel program. The $r$ values close to -1 or +1 denoted high correlation, whereas values close to zero denoted absence of correlation between the variables analyzed.

Principal component analysis (PCA) was used to identify a lower number of new alternative variables (components) that summarizes the main information and the variance of the original variables. PCA requires to decide the number of components, i.e., how many components are needed to explain the variability of the data. The criterion of Kaiser was chosen, retaining the principal components with values higher than 1, or with variance equal or higher than $70 \%$.

The factors with eigenvalues higher than one, extracted by principal components and the factorial axis were rotated by Varimax method for the FA.
The value of 0.65 was established for significant factorial weights (HAIR JUNIOR et al., 2009). The FA shows the contribution of each variable in relation to each factor; the factors were defined by water quality attributes. Four diagrams of principal components (Factor 1 and 2, Factor 3 and 4) were developed for the QWI. The data were used to develop two-dimensional and vector projection diagrams to verify the attributes that most affect the water quality in the Riacho da Bica watershed.

\section{RESULTS AND DISCUSSION}

The means found for the water quality attributes in the sampling points in the watershed for sodium adsorption ratio (SAR), electrical conductivity (EC) and the ions responsible for salinization and sodification, found in the surface and ground waters $\left(\mathrm{Na}^{+}, \mathrm{Ca}^{2+}\right.$, and $\left.\mathrm{Mg}^{2+}\right)$ are shown in Table 3.

Table 3. Means of quality indicators of waters used for irrigation in each collection point.

\begin{tabular}{lllllll}
\hline \multicolumn{1}{c}{ Water Quality Indicators } & SP1 & SP2 & SP3 & SP4 & SP5 & Overall Mean \\
\hline Sodium $\left(\mathrm{Na}^{+} \mathrm{mmol}_{\mathrm{c}} \mathrm{dm}^{-3}\right)$ & 2.29 & 2.29 & 2.71 & 2.32 & 2.53 & 2.43 \\
Calcium $\left(\mathrm{Ca}^{2+} \mathrm{mmolc} \mathrm{dm}^{-3}\right)$ & 0.42 & 0.48 & 0.77 & 0.66 & 0.65 & 0.60 \\
Magnesium $\left(\mathrm{Mg}^{2+} \mathrm{mmol}_{\mathrm{c}} \mathrm{dm}^{-3}\right)$ & 0.68 & 0.70 & 0.71 & 0.71 & 0.86 & 0.73 \\
Sodium adsorption ratio $\left(\mathrm{mm}_{\mathrm{mol}} \mathrm{L}^{-1}\right)^{0.5}$ & 3.32 & 3.13 & 3.27 & 2.85 & 3.00 & 3.11 \\
Electrical conductivity $\left.(\mathrm{dS} \mathrm{m})^{-1}\right)$ & 0.47 & 0.40 & 0.49 & 0.42 & 0.45 & 0.45 \\
\hline
\end{tabular}

SP1 = spring of the Riacho da Bica stream, in the Spout Threshold (Portal Bica) at $620 \mathrm{~m}$ altitude; SP2 = water-flow stretch, at downstream to the spring, at the Bath Spout (Banho da Bica); SP3 = before the Pinga Waterfall; SP4 = after the Pinga Waterfall; SP5 = lower course of the Riacho da Bica stream. 
The overall EC mean was of $0.45 \mathrm{dS} \mathrm{m} \mathrm{m}^{-1}$ (Table 3), which is within the limits described in the classification proposed by Ayers and Westcot (1999) for $\mathrm{C} 1$ waters, values lower than $0.70 \mathrm{dS} \mathrm{m}^{-1}$ (Table 1); this denotes that the water of the Riacho da Bica watershed presents no risk of soil salinity.

The overall SAR mean was 3.11 mmolc $^{-1}$; considering the parameters in Table 2, it is within the range of 3 the $6\left(\text { mmolc } L^{-1}\right)^{0.5}$ with electrical conductivity between 1.20 and $0.30 \mathrm{dS} \mathrm{m}^{-1}$. Thus, the water of the watershed is classified as $\mathrm{S}_{2}$, denoting risks of moderate sodification problems.

Therefore, the water of the Riacho da Bica stream was classified through as $\mathrm{C}_{1} \mathrm{~S}_{2}$, considering the means of all sampling points, presenting no risk of salinity and a medium risk of sodicity. Thus, these waters presented no restrictions for irrigation uses; regarding the sodicity, the probability of reaching dangerous levels of exchangeable sodium is low. However, waters with medium risk of sodicity should be managed with caution in fine texture (clayey) soils, since the sodium in this class of water present a significant dispersion potential in lowpermeability soils (GHEYI et al., 2010).

Similar results were found by Araújo Neto et al. (2015), who evaluated the quality of surface water for irrigation in reservoirs in the state of Ceará, Brazil, and found that more than $90 \%$ of the reservoirs present low risk of generating problems of salinity to soils $\left(\mathrm{C}_{1}\right)$, whereas with risks of causing problems of sodicity to soils varying from moderate $\left(\mathrm{S}_{2}\right)$ to severe $\left(\mathrm{S}_{3}\right)$ (AYERS; WESTCOT, 1999).

Guedes et al. (2016) evaluated ground and surface waters of the community of Barro Vermelho, Ceará, Brazil, and classified them as $\mathrm{C}_{1} \mathrm{~S}_{2}$, i.e., with no risk of salinity and moderate risk of sodicity, which probably cause problems of infiltration of sodium in soils (sodicity).

The multivariate statistics technics, factorial analysis (FA) and principal component analysis (PCA), were based on the matrix of correlation between water chemical attributes (Table 4), which showed a high number of significant $(p<0.05)$ correlations. This confirm that FA combined with PCA can provide information and, thus, be used as a viable and applicable tool to study water chemical attributes. The significant correlations found confirm that water chemical attributes are interconnected in watershed environments.

The results showed that $30 \%$ of the 55 coefficients of correlation can be used to distinguish environments (Table 4); approximately $6 \%$ of them are within the $0.6 \leq \mathrm{r}<0.9$ interval, characterized as strong correlation, and $70 \%$ are within the $0.3 \leq \mathrm{r}<0.6$ interval, characterized as moderate correlation (CALLEGARI-JACQUES, 2003).

Table 4. Matrix of correlation between indicators of quality of waters used for irrigation in the Riacho da Bica watershed. Portalegre, RN, Brazil.

\begin{tabular}{ccccccccccc}
\hline & $\mathrm{pH}$ & $\mathrm{EC}$ & $\mathrm{K}^{+}$ & $\mathrm{Na}^{+}$ & $\mathrm{Ca}^{2+}$ & $\mathrm{Cl}^{-}$ & $\mathrm{CO}_{3}^{2-}$ & $\mathrm{HCO}_{3}^{-}$ & $\mathrm{SAR}$ & Hardness \\
\hline $\mathrm{pH}$ & 1.00 & & & & & & & & & \\
$\mathrm{EC}$ & 0.05 & 1.00 & & & & & & & \\
$\mathrm{~K}$ & 0.36 & 0.35 & 1.00 & & & & & & & \\
$\mathrm{Na}$ & -0.01 & 0.10 & 0.37 & 1.00 & & & & & & \\
$\mathrm{Ca}$ & 0.50 & 0.28 & 0.49 & 0.23 & 1.00 & & & & & \\
$\mathrm{Cl}$ & 0.19 & 0.12 & 0.32 & 0.08 & 0.22 & 1.00 & & & \\
$\mathrm{CO}_{3}$ & 0.00 & 0.00 & -0.02 & -0.01 & 0.06 & 0.16 & 1.00 & & \\
$\mathrm{HCO}_{3}$ & 0.35 & 0.21 & 0.22 & 0.13 & 0.18 & -0.40 & 0.01 & 1.00 & \\
$\mathrm{SAR}^{2}$ & -0.20 & 0.01 & 0.19 & 0.92 & 0.03 & -0.01 & 0.01 & 0.14 & 1.00 & \\
Hardness & 0.39 & 0.24 & 0.35 & -0.26 & 0.32 & 0.16 & -0.08 & -0.08 & -0.59 & 1.00 \\
\hline
\end{tabular}

$\mathrm{pH}=$ potential hydrogen; $\mathrm{EC}=$ electrical conductivity; $\mathrm{K}^{+}=$potassium; $\mathrm{Na}^{+}=$sodium; $\mathrm{Ca}^{2+}=$ calcium; $\mathrm{Cl}^{-}=$chloride; $\mathrm{CO}_{3}^{2-}=$ carbonate $\mathrm{HCO}_{3}^{-}=$bicarbonate; $\mathrm{SAR}=$ sodium adsorption ratio.

The matrix shows that $\mathrm{pH}$ presents positive correlation to $\mathrm{K}^{+}(0.36), \mathrm{Ca}^{2+}(0.50), \mathrm{HCO}_{3}^{-}(0.35)$, and Hardness (0.39); thus, $\mathrm{pH}$ presented the highest correlation to $\mathrm{Ca}^{2+}$. Increases in $\mathrm{pH}$ are associated with increases in hardness; high correlations between Hardness and $\mathrm{pH}$ were found by Zamberlan et al. (2013) and Santana et al. (2016).

The presence of carbonates and bicarbonates affect the water alkalinity. Pedrazzi et al. (2014) found strong correlation between water $\mathrm{pH}$ and bicarbonate and carbonate concentrations $(\mathrm{pH}<8.3$, absence of $\mathrm{CO}_{3}^{-2}$ ). This positive correlation indicates that the $\mathrm{pH}$ values tend to increase as the elements concentration in the water is increased.

$\mathrm{EC}$ is the most used variable to evaluate salinity levels and soluble salt concentrations in waters used for irrigation. Water EC is the water capacity to conduct electricity, which is directly 
related to the quantity of salts dissolved into ion form; it increases proportionally to increases in salt concentration (LIMA; FRANÇA; LOIOLA, 2014). Thus, EC presented the highest correlation to $\mathrm{K}^{+}$, denoting that EC is affected by the concentration of ions.

Weak correlations were found between EC and calcium (0.28), and EC and hardness (0.24); however, the results indicated a trend of increases in EC as the water calcium concentration and hardness is increased (Table 4).

The representation of the factorial plan formed by F1 and F2 (Figure 2) showed that the variables that contributed with the highest factorial weights to the discrimination of the areas in relation to QWI were $\mathrm{pH}, \mathrm{K}^{+}$and $\mathrm{Ca}^{2+}$. The displacements, horizontal for F1, and vertical for F2, was more pronounced to the variables with higher factorial weight $\left(\mathrm{Na}^{+}\right.$and $\left.\mathrm{SAR}\right)$.
A

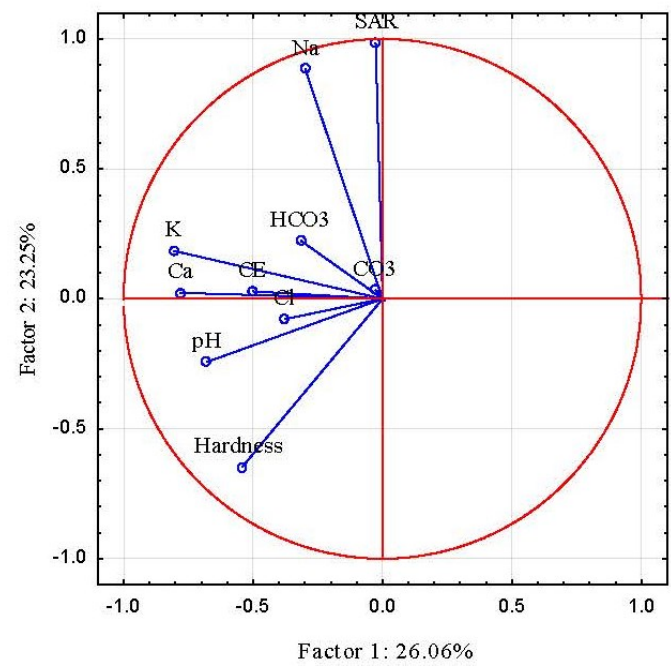

B

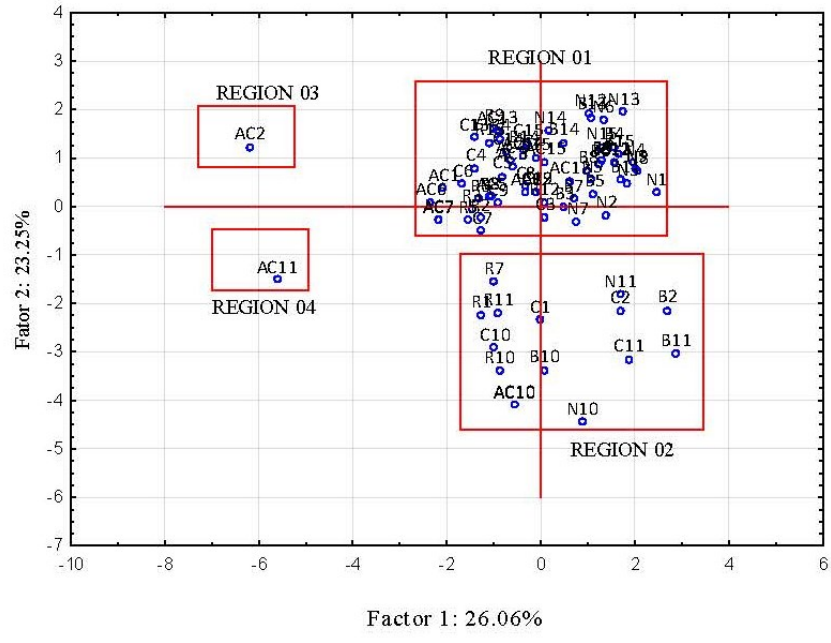

Figure 2. Distribution of the cloud of variables in the circle of correlations (A) and distribution of the cloud of points representing the correlation between the Factors 1 and 2 (B).

A large quantity of points was concentrated in the center of the circle of correlation, denoting that the results were similar; however, the variables SAR and $\mathrm{Na}^{+}$stood out, showing that they are important attributes from the QWI point of view and can be used for classification of water quality (Figure 2A).

The large cloud of data plotted opposite to the variables analyzed denotes that most of the study areas was not affected by the variables analyzed (Figure 2A). The areas were not affected enough to discriminate the environments of collection (sampling points); they were plotted in the center of the factorial plan, denoting the similarity between them (Figure 2B).

The factors F3 and F4 (Figure 3) showed that the variables with higher factorial weight for discrimination, considering the horizontal displacement in relation to $\mathrm{F} 3$, were $\mathrm{Cl}^{-}, \mathrm{HCO}_{3}$, and $\mathrm{CO}_{3}{ }^{2-}$. The areas before and after the waterfall presented $\mathrm{CO}_{3}{ }^{2-}$ as the attribute that most contributed to differentiate the sampled areas (Figure 3).

The results of the factorial analysis presented four factors, with eigenvalues higher than one (Table
5). The factors explained $26.06 \%$ (Factor 1), $23.25 \%$ (Factor 2), $14.56 \%$ (Factor 3), and 10.43\% (Factor 4) of the total variance of the attributes. These results indicate that the four factors explained approximately $74.29 \%$ of the total variance of the data. Gibrilla et al. (2011) found similar variance for four principal components, which explained $73.16 \%$ of the variance of the data.

The first factor in this type of analysis is the most important; thus, the factor F1 has the highest factorial weights for the attributes of QWI, 0.69 for $\mathrm{pH}, 0.80$ for $\mathrm{K}^{+}$, and 0.78 for $\mathrm{Ca}^{2+}$.

The first factor explained $26.06 \%$ of the total variance of the data, showing a high correlation between the attributes $\mathrm{pH}$, potassium, and calcium. The variables with higher factorial weights for this factor were potassium (0.80) and calcium (0.78), although $\mathrm{pH}(0.69)$ also presented strong correlation to this factor (Table 5).

Regarding the water quality attributes referring to availability of elements, $\mathrm{pH}$ has high correlation, but studies indicate lower variance in space (ZONTA et al., 2014). 
A

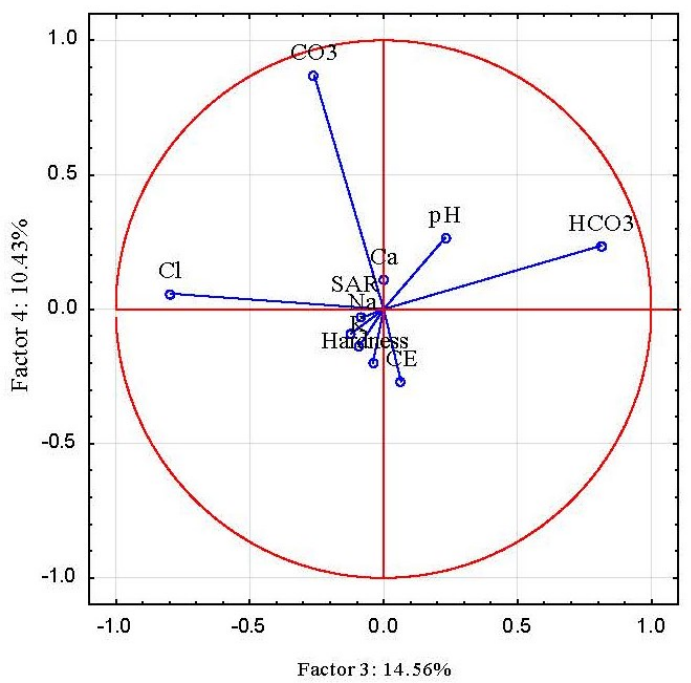

B

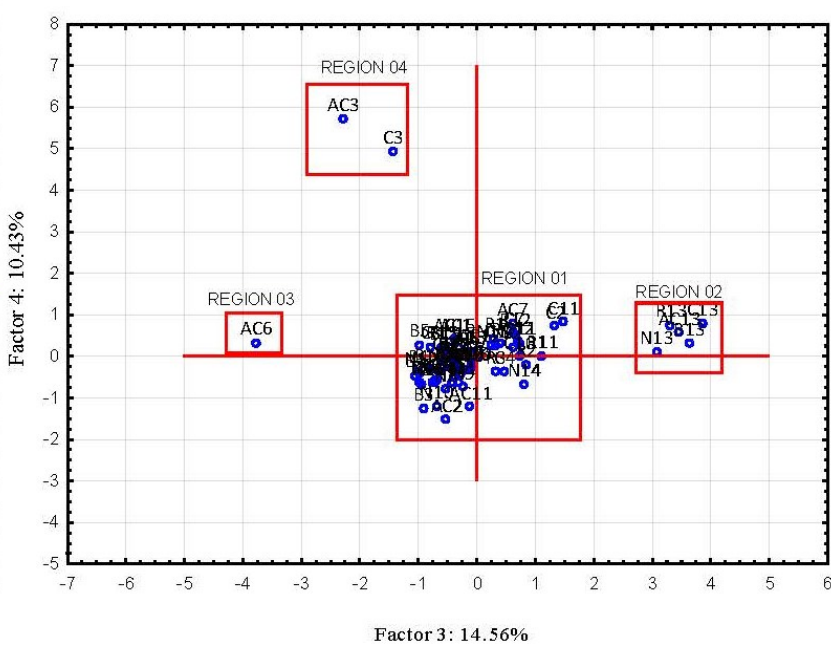

Figure 3. Distribution of the cloud of variables in the circle of correlations (A) and distribution of the cloud of points representing the correlation between the Factors 3 and $4(\mathrm{~B})$.

Table 5. Factorial axis extracted for quality of waters used for irrigation and their respective factorial weights, eigenvalues, and total and accumulated variances.

\begin{tabular}{ccccc}
\hline Quality Indicators & Factor 1 & Factor 2 & Factor 3 & Factor 4 \\
\hline $\mathrm{pH}$ & 0.69 & -0.25 & -0.23 & 0.24 \\
$\mathrm{EC}$ & 0.51 & 0.06 & 0.00 & -0.26 \\
$\mathrm{~K}^{+}$ & 0.80 & 0.24 & 0.11 & -0.08 \\
$\mathrm{Na}^{+}$ & 0.26 & 0.91 & 0.02 & -0.04 \\
$\mathrm{Ca}^{2+}$ & 0.78 & 0.05 & -0.01 & 0.14 \\
$\mathrm{Cl}^{-}$ & 0.35 & 0.04 & 0.78 & 0.23 \\
$\mathrm{CO}_{3}{ }^{2-}$ & -0.01 & 0.03 & 0.08 & 0.90 \\
$\mathrm{HCO}^{-}$ & 0.33 & 0.12 & -0.86 & 0.09 \\
$\mathrm{SAR}^{-}$ & -0.02 & 0.99 & -0.05 & 0.00 \\
Hardness & 0.57 & -0.60 & 0.18 & -0.18 \\
\hline Eigenvalues & 2.61 & 2.32 & 1.46 & 1.04 \\
Total Variance (\%) & 26.06 & 23.25 & 14.56 & 10.43 \\
Accumulated Variance (\%) & 26.06 & 49.30 & 63.86 & 74.29 \\
\hline
\end{tabular}

$\mathrm{pH}=$ potential hydrogen; $\mathrm{EC}=$ electrical conductivity; $\mathrm{K}^{+}=$potassium; $\mathrm{Na}^{+}=$sodium; $\mathrm{Ca}^{2+}=$ calcium; $\mathrm{Cl}^{-}=$chloride; $\mathrm{CO}_{3}^{2-}=$ carbonate; $\mathrm{HCO}_{3}^{-}=$bicarbonate; $\mathrm{SAR}=$ sodium adsorption ratio.

The second factor explained $23.25 \%$ of the total variance of the data, showing a high correlation for $\mathrm{Na}^{+}(0.91)$ and SAR (0.99), since SAR is an indicative of risk of sodicity.

Increases in $\mathrm{Na}^{+}$is a negative factor for environments in watersheds, since it has a large hydrated radius, promoting the replacement of $\mathrm{K}^{+}$ and $\mathrm{Ca}^{2+}$ in the soil solution, disfavoring plants in the environment, as shown by the lower factorial weight of $\mathrm{Ca}^{2+}(0.78)$ when compared to $\mathrm{K}^{+}(0.80)$.
The third factor explained $14.56 \%$ of the total variance of the data, showing a high correlation for $\mathrm{Cl}^{-}(0.78)$ and $\mathrm{HCO}^{3-}(-0.86)$; these positive and negative correlations indicate that one variable increases as the other decreases (Table 5). The fourth factor explained $10.45 \%$ of the total variance of the data, showing a high correlation to $\mathrm{CO}_{3}{ }^{2-}(0.90)$.

According to the highest factorial weights of the variables that compose the four factors, the 10 water quality variables can be represented by: Factor 
$1=\mathrm{pH}+$ Ions; Factor $2=$ dispersion of clays; Factor $3=$ chloride and bicarbonate; and Factor $4=$ carbonate. These variables are determinant for the characterization of QWI.

The FA-PCA presented four components, that explained $74.29 \%$ of the total variance of the data of water quality of the Riacho da Bica stream, showing that the most representative attributes for the variability of QWI were $\mathrm{pH}, \mathrm{K}^{+}, \mathrm{Ca}^{2+}, \mathrm{Na}^{+}$, and $\mathrm{SAR}$, which presented higher percentage in the total variance $(49.30 \%)$.

Palácio et al. (2011) found that the use of FAPCA decreased the number of surface water characteristics from seven to two components, which explained $84.04 \%$ of the total variance, showing that the most representative parameters for the variability of salinity of waters were $\mathrm{Cl}^{-}, \mathrm{EC}, \mathrm{Na}^{+}$, and $\mathrm{Mg}^{2+}$, which are related to the solubility of salts (natural or non-natural).

Bortoletto et al. (2015) evaluated the water quality of the Pirapó River basin in Paraná, Brazil, using FA and PCA for the water quality attributes monitored, and reported that the PCA decreased the number of sampling points from 9 to 5, which represents decreases in monitoring costs.

Maia, Silva and Libânio (2019) analyzed the water quality monitoring and the application of analysis multivariate in a study of sampling frequency and number of monitoring points and found that PCA is an appropriate tool for multivariate exploratory analysis, but has low practicality for similar cases. The interpretation of results may be laborious when the number of principal components shows a multidimensional space, making the visual inspection of spatial distributions expensive.

Cabral et al. (2019) evaluated multivariate statistics applied to data related to the use of wastewater for fertigation in the Semiarid region of Brazil (Patos, PB; Santa Luzia, PB; and Santana do Serido, $\mathrm{RN}$ ) and found that FA and PCA enabled the selection of two components of water quality indicators for the three municipalities evaluated, which explained $87.8 \%$ of the total variance of the data.

\section{CONCLUSION}

The water of the Riacho da Bica watershed was classified, for irrigation purposes, as $\mathrm{C}_{1} \mathrm{~S}_{2}$, which denotes no risk of soil salinity and a medium risk of soil sodicity. The application of multivariate statistics through factorial analysis (FA) and principal component analysis (PCA) generated four principal components, which allowed for the identification of the attributes that most explain the variability of the water quality in the watershed. The attributes that most explain the quality of the water used for irrigation were $\mathrm{pH}, \mathrm{K}^{+}$, and $\mathrm{Ca}^{2+}$ for Factor
01, and $\mathrm{Na}^{+}$and SAR for Factor 02. The FA combined with PCA provided a large quantity of data and, thus, was a viable and applicable tool for the study of water quality in the Riacho da Bica watershed.

\section{REFERENCES}

ALMEIDA, O. A. Qualidade da água de irrigação. 21. ed. Cruz das Almas, BA: Embrapa Mandioca e Fruticultura, 2010. 234 p.

ÁLVARES, C. A. et al. Köppen's climate classification map for Brazil. Meteorologische Zeitschrift, 22: 711-728, 2013.

ARAÚJO NETO, J. R. et al. Dinâmica da qualidade das águas superficiais para irrigação em reservatórios do estado do Ceará, Brasil. Revista Conexões Ciência e Tecnologia, 9: 51 - 60, 2015.

AYERS, R. S.; WESTCOT, D. W. A qualidade da água na agricultura. 2. ed. Campina Grande, $\mathrm{PB}$ : UFPB, 1999. 153 p. (Estudos FAO: Irrigação e Drenagem, 29).

BARROSO, A. A. F. et al. Avaliação da qualidade da água para irrigação na região Centro Sul no Estado do Ceará. Revista Brasileira Engenharia Agrícola Ambiental, 15: 1807-1929, 2011.

BORTOLETTO, E. C. et al. Monitoramento da qualidade da água da bacia do rio Pirapó, Paraná, Brasil. Revista Brasileira de Biologia, 75: 148-157, 2015.

CABRAL, J. H. A. et al. Estatística multivariada na qualidade da água residuária utilizadas na irrigação na região semiárida brasileira. Revista IberoAmericana de Ciências Ambientais, 10: 121-133, 2019.

CALLEGARI-JACQUES, S. M. Bioestatística: princípios e aplicações. Porto Alegre, RS: Artemed, 2003. $255 \mathrm{p}$

GARCIA, G. O. et al. Alterações químicas de dois solos irrigados com água salina. Revista Ciência Agronômica, 39: 7-18, 2008.

GHEYI, H. R. et al. Manejo da Salinidade na Agricultura: Estudos Básicos e Aplicados. Fortaleza, 2010. Cap. 4, p. 43-61.

GIBRILLA, A. et al. Aplicação do Índice de Qualidade da Água (WQI) e Análise Multivariada para Avaliação da Qualidade das Águas Subterrâneas do Complexo Granitóide Birimiano e da Costa do Cabo: Bacia do Rio Densu, no Gana. Water Qual 
Expo Health, 3: 63-78, 2011.

GOOGLE. Google Earth website. Disponível em: $<$ http://earth.google.com/>. Acesso em: $08 \mathrm{dez}$. 2020 .

GOMÉZ, D. M. A. et al. Estudio del modelamiento de la calidad del água del río Sinú, Colombia. Revista de Ingenierías, 12: 33-44, 2013.

GUEDES, T. A. et al. Qualidade das águas subterrâneas e superficial da comunidade de Barro Vermelho, município de Aurora, Ceará, para fins de irrigação. Revista Tecnologia \& Ciência Agropecuária, 10: 37-44, 2016.

HAIR JUNIOR, J. F. et al. Análise multivariada de dados. 6. ed. Porto Alegre, RS: Bookman, 2009. 688 p.

LIMA, J. O. G.; FRANÇA, A. M. M.; LOIOLA, H. G. Implicações hidroquímicas da condutividade elétrica e do íon cloreto na qualidade das águas subterrâneas do semiárido cearense. Revista Virtual de Química, 6: 279-292, 2014.

MAIA, K. P.; SILVA, G. A. DA; LIBÂNIO, M. Aplicação de análise multivariada no estudo da frequência de amostragem e do número de estações de monitoramento de qualidade da água. Revista Engenharia Sanitária Ambiental, 24: 1013-1025 2019.

MOSTAFAEI, A. Application of multivariate statistical methods and water-quality index to evaluation of water quality in the Kashkan River. Revista Environmental Management, 53: 865-881, 2014.

MUNIZ, D. H. F. et al. Uso de técnicas estatísticas multivariadas na avaliação da qualidade da água de corpos hídricos do distrito federal. In: SIMPÓSIO BRASILEIRO DE RECURSOS HÍDRICOS, 23., 2019, Foz de Iguaçu, Anais... Foz de Iguaçu: ABRHIDRO, 2019. p. 1-10.

PALÁCIO, H. A. Q. et al. Similaridade e fatores determinantes na salinidade das águas superficiais do Ceará, por técnicas multivariadas. Revista Brasileira de Engenharia Agrícola e Ambiental, 15: 395-402, 2011.

PEDRAZZI, F. J. M. et al. Avaliação da qualidade da água no reservatório de Itupararanga, bacia do alto Sorocaba (SP). São Paulo, UNESP, Revista Geociências, 33: 26-38, 2014.

RIBEIRO, C. S.; OLIVEIRA, G. G. A questão hídrica no semiárido baiano: conflitos pelo uso da água e as tecnologias sociais de aproveitamento de água de chuva. Revista del CESLA, 23: 1-36, 2019.

SANTANA, N. R. F. et al. Índice de qualidade da água nas nascentes do rio Piauitinga-se por análise multivariada e o uso na irrigação. Revista Brasileira de Agricultura Irrigada, 10: 999-1010, 2016.

ZAMBERLAN, J. F. et al. Índices sazonais de qualidade da água de irrigação via análise multivariada na região central do Rio Grande do Sul. Revista Irriga, 18: 376-386, 2013.

ZANELLA, M. E. Considerações sobre o clima e os recursos hídricos do semiárido nordestino. Caderno Prudentino de Geografia, 1: 126-142, 2014.

ZONTA, J. H. et al. Variabilidade espacial do solo em área cultivada com algodoeiro no cerrado do brasil. Revista Brasileira de Engenharia Agrícola e Ambiental, 18:595-602, 2014. 